\title{
EFL Teachers' Creativity and Their Teaching's Effectiveness: A Structural Equation Modelling Approach
}

\author{
Hossein Khodabakhshzadeh \\ Dr., English Department, Torbat-e Heydarieh Branch, Islamic Azad University, Torbat-e \\ Heydarieh, Iran, hkhodabakhshzade@gmail.com
}

\author{
Mansooreh Hosseinnia \\ English Department, Torbat-e Heydarieh Branch, Islamic Azad University, Torbat-e \\ Heydarieh, Iran, mansoorehhossinnia@yahoo.com
}

\section{Hossein Abedi Moghadam}

Management Department, Jajarm Branch, Elmikarbordi University, Bojnord, Iran, abedi7723@chmail.ir

\section{Fatemeh Ahmadi}

English Department, Torbat-e Heydarieh Branch, Islamic Azad University, Torbat-e Heydarieh, Iran, fatemeh.ahmadi51@yahoo.com

Due to the importance of creativity in teaching and learning, this study was conducted to study teachers' creativity and its relationship with their teaching's effectiveness. Another aim of this study was to measure the creativity among men and women teachers at English institutions in Iran. A sample of 325 EFL Iranians' teachers was randomly chosen and was rated on the ELT-CS and teaching effectiveness scale. With this aim, validated and reliable scales of assessing creativity (ELT-CS) of EFL teachers teaching effectiveness scale were used. After gathering the questionnaires, data was analysed by structural equation modelling approach. According to the results, five subscales of creativity have a significant relationship with teaching effectiveness. Also, the results have shown that there is a significant difference between gender and teachers' creativity.

Keywords: creativity, teaching effectiveness, EFL teachers, creativity dimensions, teaching

\section{INTRODUCTION}

In the recent decade creativity has become under consideration in all professions, because "creativity becomes a force of great value when it is applied to causes that benefit humankind and the world at large" (Livingston 2010, p. 61). It is vital for

Citation: Khodabakhshzadeh, H., Hosseinnia, M., Moghadam, H. A., \& Ahmadi, F. (2018). EFL Teachers' Creativity and Their Teaching's Effectiveness: A Structural Equation Modelling Approach. International Journal of Instruction, 11(1), 227-238. https://doi.org/10.12973/iji.2018.11116a 
instructors and learners to consider their own perspectives on and feelings of creativity, with an expansion of attention on creativity in learning and ELT. (Tin, Manara \& Ragawanti, 2009, p.385). A teacher is supposed to be creative while "combines the existing knowledge with a new way that is new or unique or introduces a new process to nourish cognition to obtain a useful outcome (learning)" (Afida, Aini \& Rosadah, 2013, p.9).

It is supposed that teachers' creativity influence in the amount of their teaching's effectiveness. According to Borich (1994), for teaching effectiveness, a teacher should prefer teaching and effective learning, and teaching should be obvious, various, and promote the success amounts of students in order to achieve their educational aims.

Rushton et al. (1983) in their study examined "personality characteristics associated with research creativity and teaching effectiveness in university psychology professors". They found that "the effective teacher is best described as liberal, sociable, showing leadership, extraverted, nonanxious, objective, supporting, non-authoritarian, nondefensive, intelligent, and aesthetically sensitive". In another study, Ashraf and Hosseinnia (2016) have shown that by the increase of commitment of teachers to professional ethics their teaching effectiveness has increased too. So, professional ethics plays an important role in the effectiveness of every teacher.

Regarding the important role of creativity on teaching and learning and on teachers' effectiveness, this study aims to investigate teachers' creativity and its relationship with their teaching's effectiveness and to measure creativity among men and women teachers at schools and English institutions in Iran.

\section{Research Questions}

Based on what was mentioned above, the present study aims to answer the following research questions:

- Is there any significant relationship between Iranian EFL teachers' creativity and their teaching's effectiveness?

- Is there a substantial difference between the men and women EFL teachers' ability to enhance their learners' creativity skill in Iran?

\section{REVIEW OF LITERATURE}

\section{Creativity}

Creativity is the utilization of imagination and new ideas to be more effective and successful.

Goltan (1869) was the first person who presented creativity and Guilford (1950) and Torrance (1962) studied creativity scientifically. (Ghonsooly, Shoqi, 2012, p.161). Language teaching methodologies recently are based on student-centered and interaction-based methods and have been employed open-ended elements (Dornyei, 2005, P. 205). So, in these kinds of approaches such as communicative approach and task-based, there was a need for the imagination and creativity of both language teachers 
and learners that had not any place in the old rote-learning teaching strategies and creativity in students (Cheng, 2010).

Craft (2001) referred to the distinction of "little c" creativity from "high creativity" that big $\mathrm{c}$ affects a lot on society whereas the little $\mathrm{c}$ dealt with everyday creativity and is more relevant to the field of education.

There is a difference between teaching creatively and teaching for creativity. Teaching creativity use of imaginative approaches to make learning more effective; whilst, teaching for creativity expand nourishment of creative abilities of young people. In other words, teaching for creativity is more deals with learner empowerment; on the other hand, teaching creatively has more focus on effective teaching (Jeffrey \& Craft, 2004).

Traditionally two popular tests of creativity were: 1 . Torrance Tests of Creative Thinking (TTCT) (Torrance, 1974) and 2. the Wallach-Kogan Creativity Tests (WKCT) (Wallach \& Kogan, 1965) which were mostly employed by the researcher.

Also, some researchers such as Pishghadam, Baghaei, Shayesteh, (2012) in an attempt constructed an English language teacher creativity scale (ELT-CS) for measuring creativity of English teachers and examined "validity of the hypothesized factor structure of the ELT-CS questionnaire through Rasch rating scale model (RSM)". Maley \& peachy (2010) in an attempt proposed some creative activities can be used in ELT classrooms. Cubukcu (2010) in his study examined the role of poetry in creative thinking at ELT classes. He argued that "Poetry gives students a creative way to construct and express their ideas, and it gives teachers a new way to listen" (p.789). In another study, Ghonsooly, Shoqi (2012) investigated the effect of foreign language learning on individuals' divergent thinking abilities. Their results showed that "learning English as a foreign language to an advanced level significantly enhances all four divergent thinking abilities, i.e., fluency, elaboration, originality and flexibility". Pishghadam and Ghorbani Nejad and Shayestehthe (2012) examined relationship between teachers' creativity and their success in classroom. Their finding revealed that a series of creativity dimensions can significantly predict teacher success. Tin et al. (2009) in an attempt examined the perspectives on creativity in Indonesian students' and teachers' evaluation of short poems created by a group of Indonesian university students. Also, Tin (2013) in another attempt argued the way of transformation of language learning tasks into creative tasks. It offered two situations that improve creativity: "the use of multicultural experiences and constraints". Sarooghi et al. (2015) examined the relationship between creativity and innovation. They did a meta-analysis of 52 empirical samples strong and found positive relationship between creativity and innovation specially at individual level.

\section{Teachers' effectiveness}

Because teachers as the most important members of the society are responsible for having depositary of all the resources - the human intelligence and they are holding the luck of other individuals and the civilization in their hands, they have achieved an exclusive position in societies all over the world (Borkar, 2013). 
According to Borkar (2013), the effectiveness of the educational system largely depends upon the effective teachers. Paolini (2015) mentioned that "exceptional instructors are culturally sensitive, respectful, passionate, and charismatic. They challenge students to work to their potential by setting high, yet reasonable expectations, emphasizing open communication, and asking higher-order thinking questions that stimulate discussion" (p.21).

Barry (2010) argues that teaching effectiveness can be understood by examining what effective teachers know and do in their daily professional practice. Also, he (2010) adds that "these involve a deep understanding of subject matter, learning theory and student differences, planning, classroom instructional strategies, knowing individual students, and assessment of student understanding and proficiency with learning outcomes" (p.34).

According to Barry (2010) "Effective teachers know who their students are. They know their students' learning styles, their strengths and their deficits as learners. They are masters of their subject matter...but more importantly, effective teachers are always focused on their students' learning" (p.8).

Marsh and Roche (1997) argued about the evaluation of teaching effectiveness that "teaching effectiveness can be evaluated by current students, former students, the teacher himself or herself, colleagues, administrators, or trained observers. Teachers' self-evaluations are useful because they can be collected in all educational settings" (p. 1189).

During the recent decades, researchers have carried out much about teacher effectiveness. Chi et al. (2014) in their study with the aim of investigating the effects of well-being, social support, principal leadership on teaching effectiveness, the mediating impact of well-being between social support and teaching effectiveness, and the moderating effect of principal leadership between social support and teaching effectiveness, found that "(1) Social support will positively and significantly affect teaching effectiveness, (2) social support will positively and significantly affect wellbeing, (3) well-being will positively and significantly affect teaching effectiveness, (4) principal leadership will positively and significantly affect teaching effectiveness, (5) well-being has mediating effect between social support and teaching effectiveness, and (6) principal leadership has no moderating effect between social support and teaching effectiveness" (p.117). In another study, Reynolds et al. (2002) made a comparison among Professional Development School (PDS) and non-PDS graduates in the United States in terms of retention in teaching, teaching effectiveness, and perceptions of professional preparation. According to their results, there were no significant differences in retention in teaching and effectiveness and small but significant differences favouring PDS over non-PDS teacher education programs.

\section{METHOD}

The participants in this study are 325 EFL teachers who are teaching English in public schools (125) or private English institutions (200) in several cities of Iran including Mashhad, Jajarm, Bojnord, Kashan, Torbat e heydarie, Neyshabour, Tehran, and Tabriz. 
They were randomly chosen. The English teachers aged 24 to $43(M=27.2)$ with a range of 3 to 20 years of teaching experiences $(M=15)$. The teachers had all majored in the various branches of English such as teaching, literature, and translation at B.A. ( N= $200)$ or M.A. $(\mathrm{N}=100)$ or $\mathrm{PhD}(\mathrm{N}=25)$.

\section{Instruments}

Two instruments were used in this study: An English language teacher creativity scale (ELT-CS) and Teacher effectiveness scale.

\section{English Language Teacher Creativity Scale (ELT-CS)}

In order to measure how much EFL teachers cultivate their students' sense of creativity ELT-CS, constructed and validated by Pishghadam, Baghaei and Shayesteh (2012), was conducted. The scale comprises 60 multiple choice items ranging from "always" to "never", requiring 20 minutes to complete. ELT-CS is multidimensional and includes 7 dimensions namely Originality and Elaboration, Fluency and Flexibility, Person (Teacher), Press (Environment) and Materials, Motivation, Independent Learning (Autonomy) and Brainstorming. The items of this questionnaire were constructed in a way that should be filled by the students of their teachers. But in this research, the researcher has changed its wording which should be filled by the teachers themselves. For example, the second item of it "Asks us synonyms and antonyms" has changed into "we ask students synonyms and antonyms". With this aim, the questionnaire was validated again by the researcher. Rasch rating scale model (RSM) (Andrich, 1987) was utilized to substantiate the construct validity of the scale. Adopting consecutive approach, each dimension was ratified separately. The reliability estimates obtained for each of the seven underlying factors were as follows: Originality and Elaboration $=.80$, Fluency and Flexibility $=.75$, Person (Teacher) $=.79$, Press (Environment) and Materials $=.81$, Motivation $=.78$, Independent Learning (Autonomy) $=.72$ and Brainstorming $=.76$. Further, the overall reliability gained by Cronbach Alpha for the data in this study is 0.83 .

\section{Teacher effectiveness scale}

Teacher effectiveness questionnaire was developed and validated by Umme Kulsum in 2000. It consisted of 60 items. It included two parts: 1. demographic part and 2. the items. The scale has five distinct areas that included classroom management, the preparation for teaching and planning, knowledge of subject matter, interpersonal relations, and teacher characteristics (Buela and Joseph, 2015). Classroom management refers to the ability of teacher to successfully communicate, motivate, the students and evaluate the teaching-learning process and also to maintain discipline in the classroom within the framework of a democratic organization. Preparation for teaching and planning refers to the ability of teacher in preparing, planning and organizing for teaching in accordance with the course objectives by using different source materials. Knowledge of subject matter is the ability of teacher for acquiring, retaining, interpreting and making use of the content of the subjects he/she is dealing within classroom situations. Interpersonal relations refer to the ability of the teachers to adopt themselves to maintain cordial relations with their colleagues, pupils, their parents and 
other persons in the community with whom he/she is to interact as an integral part of his/her profession. Teacher characteristics refer to the personality make-up and its behavioural manifestations that have their own level of acceptability in the teaching profession. This item is based on Likert scale. The respondent has to encircle only one numerical of each role/function of a teacher. The reliability of this scale was calculated by Goad (2011) as 0.85 .

\section{Procedures}

At first, some cities of Iran were randomly chosen. Then, among those cites, some English institutions were randomly chosen. So, the researcher gave the questionnaires to the supervisor of each English institution and asked him/her randomly chooses some teachers and asks them to answer the questionnaires. The data collection done through two questionnaires (English language teacher creativity scale \& Teachers Effectiveness scale) started in November, 2016 and ended in December.

After completion of distribution of questionnaires, the supervisors delivered them to the researcher. The total number of every questionnaire was 325 and all of them were delivered to the researchers. Then, the questionnaires were gathered and the data was entered into and processed with Structural Equation Modelling approach.

\section{FINDINGS}

SPSS was utilized to analyse descriptive statistics, Pearson correlation formula, and independent sample t-test. There were two main variables (teachers' creativity and their teaching's effectiveness) in the study. The mean, standard deviation, and correlation matrix of the variables are presented in Table 1.

Table 1

Descriptive Statistics of Statistics of teachers' creativity and their teaching's effectiveness

\begin{tabular}{llllll}
\hline & N & Minimum & Maximum & Mean & Std. Deviation \\
\hline Teachers' Creativity & 325 & 89.00 & 257.00 & 187.521 & 14.574 \\
Teaching Effectiveness & 325 & 92.00 & 249.00 & 203.079 & 16.210 \\
\hline
\end{tabular}

The possible range of score for both questionnaires is between 60 and 300 . As it can be seen in Table 1 the mean score of the teachers' report in Teaching Effectiveness was 203.079 with standard deviation of 16.210 and the mean score of the teachers' report in Teachers' Creativity was 187.521 with standard deviation of 14.574. In addition, the table shows that number of teachers was 325 .

- Is there any significant relationship between Iranian EFL teachers' creativity and their teaching's effectiveness?

To assess the first Research Question, path analysis was used. Figure 1 indicates the interrelationship among subscales of Teachers' Creativity, and overall Teaching Effectiveness. A number of fit indices were examined to evaluate the model fit: the chisquare magnitude which shouldn't be significant, the chi-square/df ratio which should be lower than 2 or 3, the comparative fit index (CFI), the good fit index (GFI) with the cut 
value greater than .90, and the Root Mean Square Error of Approximation (RMSEA) of about .06 or .07 (Schreiber, Nora, Stage, Barlow, \& King, 2006). As the model shows, all the fit indices, CFI (.94), GFI (.97), the chi-square/df ratio (2.201), and RMSEA (.063), lie within the acceptable fit thresholds based on Schreiber, Nora, Stage, Barlow, and King (2006). Hence, it can be concluded that the proposed model had a perfect fit with the empirical data.

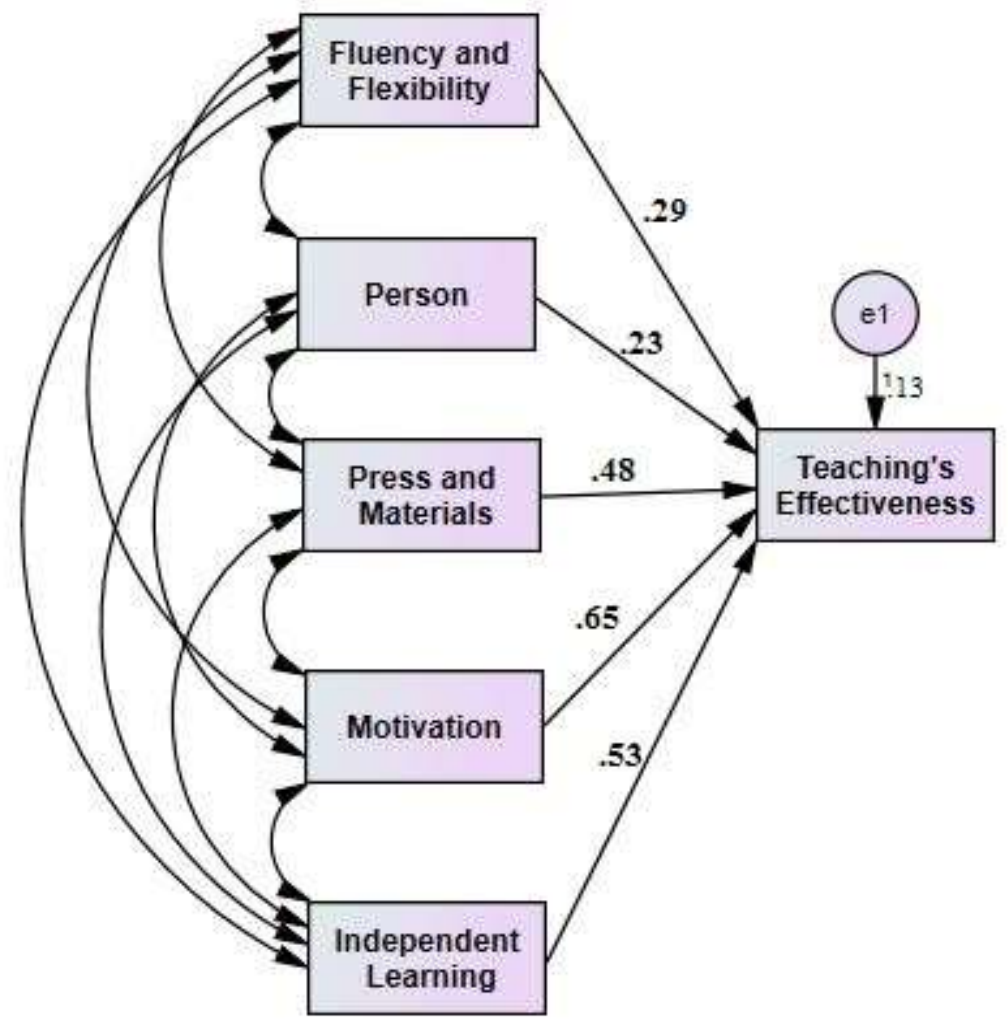

Figure 1

Interrelationship among subscales of Teachers' Creativity, and overall Teaching Effectiveness

To assess Research Question 1, SEM was conducted. As indicated in Figure 1, two nonsignificant paths from seven subscales of Teachers' Creativity (Originality and Elaboration and Brainstorming) are removed from the model. As the figure demonstrates Fluency and Flexibility $(\beta=.29, \mathrm{p}<0.05)$, Person $(\beta=.23, \mathrm{p}<0.05)$, Press (Environment) and Materials $(\beta=.48, p<0.05)$, Motivation $(\beta=.65, \mathrm{p}<0.05)$, and Independent Learning (Autonomy) $(\beta=.53, p<0.05)$ are positive and significant predicators of Teaching Effectiveness.

Table 2 indicates the results of correlation between subscales of Teachers' Creativity, and overall Teaching Effectiveness. 
Table 2

Results of Correlation between subscales of Teachers' Creativity, and overall Teaching Effectiveness

\begin{tabular}{|c|c|c|c|c|c|c|c|}
\hline & $\begin{array}{l}\text { Originality } \\
\text { and } \\
\text { Elaboration }\end{array}$ & $\begin{array}{l}\text { Fluency } \\
\text { and } \\
\text { Flexibility }\end{array}$ & Person & $\begin{array}{l}\text { Press and } \\
\text { Materials }\end{array}$ & Motivation & $\begin{array}{l}\text { Independent } \\
\text { Learning }\end{array}$ & Brainstorming \\
\hline $\begin{array}{l}\text { Teaching } \\
\text { Effectiveness }\end{array}$ & .09 & $.33^{* * *}$ & $.30^{* * *}$ & $.58^{* * 6}$ & $.72^{* * \%}$ & $.65^{3 * 6}$ & $.15^{*}$ \\
\hline
\end{tabular}

***orrelation is significant at the level of 0.01

As the results indicates, among seven subscales of Teachers' Creativity, Originality and Elaboration has the lowest relationship with Teaching Effectiveness $(r=.09, p>0.05)$ which was not significant and Motivation has the highest relationship with Teaching Effectiveness $(r=.72, p<0.05)$.

To answer the second research question aiming at examining whether teachers' ability to enhance their learners' creativity skill differ significantly between men and women an independent-samples t-test was performed. Table 3 shows the descriptive statistics of men and women scores in teachers' creativity. Results of the independent-samples t-test is presented in Table 4 .

Table 3

The Descriptive Statistics of Males and Females' Scores in Teachers' creativity

\begin{tabular}{lllll}
\hline & Gender & $\mathrm{N}$ & Mean & Std. Deviation \\
\hline \multirow{2}{*}{ Teachers' Creativity } & $\mathrm{F}$ & 181 & 195.452 & 15.321 \\
& $\mathrm{M}$ & 144 & 178.230 & 13.202 \\
\hline
\end{tabular}

As the table shows, the mean score of women (195.452) in Teachers' Creativity questionnaire is higher than men (178.230). To find that whether this difference is significant t-test was run.

Table 4

Results of the independent-samples t-test

\begin{tabular}{lccccc}
\hline \multicolumn{7}{c}{ t-test for Equality of Means } \\
\hline & $\mathrm{t}$ & $\mathrm{df}$ & Sig. (2-tailed) & Mean Difference & Std. Error Difference \\
Teachers' Creativity & 3.441 & 323 & .000 & -3.520 & 2.578 \\
\hline
\end{tabular}

Levene's test indicated homogeneity of variance on the teachers' creativity. As indicated in table 4, there is a significant difference between gender and teachers' creativity. Therefore, according to the results, women are more creative in teaching than men.

\section{CONCLUSION AND PEDAGOGICAL IMPLICATIONS}

Evidently the notion of creativity is prominent to teachers, due to its direct impact on learning, teaching and more importantly on learners' future lives (Pishghadam, Baghaei and Shayesteh, 2012, p. 2). And the purpose of this research was to examine teachers' creativity and its relationship with their teaching's effectiveness. Another aim of this study was to measure creativity among men and women teachers. 
The first research question was: Is there any significant relationship between Iranian EFL teachers' creativity and their teaching's effectiveness?

According to the data and results, it was found that seven subscales of creativity have a significant relationship with teaching effectiveness. So, being a creative teacher influences the amount of their teaching's effectiveness. The seven subscales are Originality and Elaboration, Fluency and Flexibility, Person (Teacher), Press (Environment) and Materials, Motivation, Independent Learning (Autonomy) and Brainstorming. As the results indicate, among seven subscales of Teachers' Creativity, Originality and Elaboration has the lowest relationship with Teaching Effectiveness which was not significant and Motivation has the highest relationship with Teaching Effectiveness. So, teachers' motivation on teaching affects teachers' effectiveness. In other words, by increase of motivation of teachers, their teaching effectiveness has increased too. Ashraf and Hosseinnia (2017) in their study examined the relationship between professional ethics and teacher effectiveness. Their results have shown that there is a significant relationship between those two variables. So, teaching effectiveness has a relationship with both creativity and professional ethics. In another study, Pishghadam et al. (2011) found learner creativity as an important factor in foreign language achievement. Also, Nami et al. (2014) in their study investigated relationship between students' creativity and academic achievement. They found a positive relationship between students' creativity and academic achievement.

The second research question was: Is there a substantial difference between the men and women EFL teachers' ability to enhance their learners' creativity skill in Iran?

Finding revealed that there is a significant difference between gender and teachers' creativity. Therefore, according to the results, women are more creative in teaching than men. The results are justifiable if we delve into the nature of creativity and its underlying subscales. Since creativity deals with factors like motivation, autonomy, and originality it is quite fair to claim that the teachers who better enhance creativity in their learners are more successful in reality. This is identical to Csikszentmihalyi's (1996) idea that teachers may be important gatekeepers of learners' creative potentials. Regarding Person (Teacher), it is totally meaningful to say generally features like teachers' attention to students' ideas, not being exam-oriented and trying to have a friendly class leads to teacher success. This supports Tamblyn's (2000) claim that successful teachers are creative, flexible, skilful, warm, and humorous. An investigation by Forisha $(2015$, p.1) regarding creativity of women and men "showed that creative ability and vividness of imagery are related in women, while creative ability and creative production are related in men". In other study done by Kemmelmeier \& Walton (2016, p.78), Results "revealed gender differences in self-assessment of creativity such that women seemed to be somewhat more attuned to the objective level of the originality of their creative performance than men".

Manifestly, readers must keep in mind that a study such as the present one has its own restrictions. The scale was originally developed for teachers but filled by the students, but here the researcher has changed the items according to the teachers. Generally, a person has a tendency to evaluate himself/herself positively. So, teachers may consider 
their performance better than their reality. Thus, this matter is one of the limitations of this study. Also, the participants involved in this study were selected from a number of English language institutes which were not representative of the big population of English language teachers and learners of Iran. In reference, universal generalization of the findings is not recommended; yet, the implication of the data might be useful for similar contexts and samples.

Results of this study provide teachers and researchers with theoretical and pedagogical implications ability to enhance their learners' creativity skills. It provides a framework for teachers and students to investigate their own views on and perceptions of creativity. It can be of great help to researchers interested in studying creativity and institute managers in recruiting eligible teachers who are able to identify and cultivate learners' creative potential. It encourages teachers to develop themselves in all dimensions of creativity in order to teach more effectively and to meet educational goals. According to Chien and Hui's (2010) conception, appropriate training courses would be planned in practice to elevate teachers' creativity knowledge and education. Over and above, this study can exclusively serve miscellaneous ways of improving English teachers' creativity fostering behaviours. By using creativity developing techniques and realizing their role in bringing change in learning and teaching context, the teachers can make progress in achieving their ultimate capabilities and can make progress in helping learners develop patterns and strategies for thinking creatively, a skill that will definitely serve them well as they move toward their unwritten futures. Moreover, by providing training courses in practice, creativity can simplify exploring successful teachers while encountering multiple situations. Therefore, this can be beneficial for administrators of English language institutes to recruit those teachers who will be more effective in their career by using ELT-CS. This can ultimately help them to increase their effectiveness in their classes.

Some suggestions were offered by the researchers for further studies in this respect: other studies can be done to overcome the mentioned limitation and evaluate the creativity of teachers in teaching by their students. Also, other researchers can do researches to find probable relationships between EFL teachers' creativity with other variables such as their self-esteem. Another possible research could focus on ways to improve teachers' tendency toward implementing more creative methods and tasks in the classroom.

\section{REFERENCES}

Ashraf, H., \& Hosseinnia, M. (2017). EFL teachers' commitment to professional ethics and their teaching's effectiveness: A relationship study. Manuscript submitted for publication.

Afida, A., Aini, H., \& Rosadah, A. M. (2013). A review of research on creative teachers in higher education. International Education Studies, 6, 8-14.

Barry, R. A. (2010). Teaching effectiveness and why it matters. Marylhurst University and the Chalkboard Project. 
Borich, G. D. (1994). Observation skills for effective teaching. New York: Macmillan.

Borkar, U. A. (2013). A study of teacher effectiveness of secondary school teachers in relation to teacher stress. International Journal of Humanities and Social Science Invention, 2(12), 13-16.

Buela, S., \& Joseph, M. (2015). Relationship between personality and teacher effectiveness of high school teachers. The International Journal of Indian Psychology, 3(1). Retrieved May 5, 2016 from http://www.ijip.in

Cheng, V. M. Y. (2010). Tensions and dilemmas of teachers in creativity reform in a Chinese context. Thinking Skills and Creativity, 5, 120-137.

Chi, H., Yeh, H., \& Wu, S. F. (2014). How well-being mediates the relationship between social support and teaching effectiveness. Journal of Education and Learning, 3(4), 117-130.

Chien C, \& Hui AN. Creativity in early childhood education: Teachers' perceptions in three Chinese societies. Thinking Skills and Creativity, 5, 49-60.

Craft, A. (2001). Little c creativity. In A Craft, B Jeffrey, M Liebling (Eds.), Creativity in education. Continuum, London.

Csikzentmihalyi, M. (1996). Creativity: Flow and the psychology of discovery and invention. New York: Harper Collins.

Cubukcu, F. (2010), Creative thinking and poetry in ELT classes. International Conference on New Trends in Education and Their Implications, Antalya-Turkey. Retrieved May 5, 2016, from www.iconte.org/FileUpload/ks59689/File/173.pdf.

Dornyei, Z. (2005). The psychology of the language learner. Mahwah NJ: Lawrence Erlbaum Associates, Inc. Retrieved May 5, 2016, from http://www.medu.ir/portal/File/ShowFile.aspx?ID=be11ff9f-1979-400e-90ca$74 \mathrm{f} 42 \mathrm{~d} 9287 \mathrm{c} 4$.

Forisha, B. L. (2015). Creativity and imagery in men and women. Perceptual and Motor Skills Journal, 47, 155-166.

Ghonsooly, B., \& Shoqi, S. (2012). The effects of foreign language learning on creativity. English Language Teaching Journal, 5, 161-167.

Hosseinnia, M. (2017). EFL teachers' emotional intelligence and their teaching's effectiveness: A relationship study. A presented article in $37^{\text {th }}$ Annual Thailand TESOL International conference "ELT pathways to professional excellence".

Jeffrey, B., \& Craft, A. (2004). Teaching creatively and teaching for creativity: Distinctions and relationships. Educational Studies, 30(1), 77-87.

Kemmelmeir, M., \& Walton, A.P. (2016). Creativity in men and women: Threat, otherinterest, and self-assessment. Creativity Research Journal, 28(1),78-88.

Livingston, L. (2010). Teaching creativity in higher education. Arts Education Policy Review, 111, 59-62. 
Maley, A., \& Peachey, N. (2010). Creativity in the language classroom. British Council.

Open Lean Works, Tess India. Retrieved May 5, 2016, from http://www.open.edu/openlearnworks/mod/oucontent/view.php?id=81160

Paolini, A. (2015). Enhancing teaching effectiveness and student learning outcomes. The Journal of Effective Teaching, 15(1), 20-33.

Marsh, H. W., \& Roche, L. A. (1997). Making students' evaluations of teaching effectiveness effective. The American Psychological Association, Inc, 52(11), 11871197.

Nami, Y., Marsooli, H., \& Ashouri, M. (2014). The relationship between creativity and academic achievement. Procedia - Social and Behavioral Sciences, 114, 36-39.

Pishghadam, R., Baghaei, P., \& Shayesteh, SH. (2012). Construction and validation of an English language teacher creativity scale (ELT-CS). Journal of American Science, 8, 497-508.

Pishghadam, R., Ghorbani Nejad, T., \& Shayesteh, Sh. (2012). Creativity and its relationship with teacher Success. BELT Journal · Porto Alegre, 2(3), 204-216.

Pishghadam, R., Khodadady, E. \& Zabihi, R. (2011). Learner creativity in foreign language achievement. European Journal of Educational Studies, 3, 465-472.

Rushton, J. P., Murray, H. G., \& Paunonen, S. V. (1983). Personality, research creativity, and teaching effectiveness in university professors. Scientometrics, 5(2), 93116.

Reynolds, A., Ross, S. M., \& Rakow, J. H. Teacher retention, teaching effectiveness, and professional preparation: a comparison of professional development school and non-professional development school graduates. Teaching and Teacher Education, 18, 289-303.

Sarooghi, H., Libaers, D., \& Burkemper, A. (2015). Examining the relationship between creativity and innovation: A meta-analysis of organizational, cultural, and environmental factors. Journal of Business Venturing, 30(5), 714-731.

Tamblyn, P. (2000). Qualities of success: Lessons from a teacher career. Education Canada, 40(1), 16-19, 2000.

Tin, T. B. (2013). Towards creativity in ELT: The need to say something new. ELT Journal, 67, 385-397.

Tin, T. B., Manara, C. H., \& Ragawanti, D.T. (2009). Views on creativity from an Indonesian perspective. ELT Journal, 64(1), 75-84.

Wallach, M. A., \& Kogan N. (1965). Modes of thinking in young children: A study of the creativity intelligence distinction. Holt, Rinehart \&Winston, New York. 